АНАТОЛІЙ КРУГЛАШОВ (ANATOLIY KRUGLASHOV)

Чернівецький національний університет

ім. Юрія Федьковича, Україна

(Yurii Fedkovych Chernivtsi National University, Ukraine)

\title{
Досвід політичних трансформацій в Україні: від рефлексії мімікрії до імперативу системної свропеїзації
}

\section{Ukraine's Experience of Political Transformation: From 'Mimic Reflexes' to the Imperative of Systematic Europeanisation}

The article concerns the main trends of post-communist development of Ukraine from the point of view of achievements and failures in the social and political transformations carried out during its course. The political system, the process of democratisation, the evolution of the party system and the electoral process are of core importance in the author's analysis. The author discusses the difficulties related to the formation of stable liberal democracy and considers these alongside external and internal factors inhibiting the emergence of modern statehood resistant to numerous challenges.

The potential and limitations of civic society's influence on political processes in the country are also taken into account. The difficulties in creating a national elite capable of the effective implementation of agreed reforms and responsible interaction with citizens are shown. The problems of economic transit to a modern market economy are briefly discussed. The main social contradictions resulting from the oligarchization of both the economic and political spheres of the state are analysed. It is stated that the revolutionary mood generated during the events of 2013-2014 has been exhausted.

Particular attention is paid to the importance of Ukraine's European policy, its rapprochement with the European Union (EU), including counteracting the military-political and other pressures from Russia. Attention is drawn to the long-term tendency of the political elite in Ukraine to simulate reforms aimed at systematic Europeanisation of the country. Initial classification of the social groups in Ukrainian society is proposed from the point of view of their attitude towards reforms implemented in the country. The special importance of both internal and external support from the EU and the international community, particularly countries friendly to Ukraine, is emphasised.

Keywords: democratic transit, Ukraine's statehood, reforms, process of Europeanisation. 


\section{Вступ}

Досить складно для науковця, який займається вивченням соціальнополітичних трансформацій України, дати їм збалансовану, виважену, академічно чітку загальну характеристику. Адже сучасний стан розвитку України відзначається суперечливістю і далекий від однозначності. 3 одного боку, українська державність перейшла через дуже важливий, хоч би за своїм психологічним значенням, бар'єр свого 25-річного існування і довела власну певну життєстійкість навіть перед такою потужною загрозою і викликом, як російська агресія. Проте остання забрала й далі продовжує забирати в українського народу численні жертви, в тому числі серед цивільного населення, призвела до появи понад мільйону переміщених осіб, втрати - сподіваюсь, лише тимчасової Автономної Республіки Крим, частини території Донецької і Луганської областей України. На превеликий жаль, цей конфлікт, ця спровокована не українською стороною агресія і війна на Сході тривають із поки що невизначеною перспективою завершення. Разом із цим, українська держава довела, що вона володіє певним ресурсом життєстійкості і, що дуже важливо, цей ресурс стійкості це насамперед - віддана, а нерідко й героїчна підтримка власної країни з боку ії громадян: тих, які захищають Україну зі зброєю в руках, хто через участь у доволі потужному волонтерському русі допомагає захищати свою державу, і тих, хто протидіє численним провокаціям і підступам недругів України всередині і назовні держави.

За таких несприятливих умов попередні підсумки здійснених соціально-політичних трансформацій $є$ неоднозначними. Адже, попри окремі досягнення і деякі, хоча й скромні, на мій погляд, здобутки, Україна втратила дуже багато на своєму шляху до європейської форми й змісту національного розвитку. І тут радше можна вести мову про те, чого українські громадяни не досягли, а не тільки про те, що вони здобули. Тому структура моєї статті буде базуватися на двох основних складових частинах. По-перше, на аналітичній оцінці шляху, пройденого Україною за роки ії̈ незалежності. По-друге, на авторському узагальненні результатів політичних трансформацій з точки зору основних її параметрів, від стану політичної системи до розвитку громадянського суспільства, наскільки це можна висвітлити в стислій текстовій формі. При цьому я буду використовувати як вітчизняні, так і зарубіжні джерела, праці науковців, які предметно досліджують пострадянську Україну. Серед них заслуговують 
на особливу увагу розвідки Тараса Кузьо ${ }^{1}$, Андерса Аслунда ${ }^{2}$, Богдана Гарасиміва ${ }^{3}$, Олександра Фісуна ${ }^{4}$, Наталії Ротар ${ }^{5}$, Юрія Мацієвського Анатолія Романюка, Лариси Кочубей та інших дослідників 7 . Також у тексті буде використовуватись власний досвід не лише наукової, але й громадської та управлінської діяльності в період, що розглядається.

\section{Від Terra Sovietica до свропейської країни: (довго)триваюча подорож України}

Почну насамперед $з$ того, що Україна $з$ кінця 1980-х та початку 1990-х років XX ст., з труднощами та затримками, але рухалась все ж таки у напрямку відходу від теренів умовного континенту «Terra sovietica» до сучасної європейської цивілізації та відповідних форм державності. Стартовий потенціал України під час розпаду СРСР був доволі високим i багатообіцяючим. Тут варто згадати, що на початку періоду незалежності в Україні панували досить оптимістичні очікування, які грунтувалися на тому, що серед тодішніх республік Радянського Союзу Україна мала значний потенціал для успішного незалежного розвитку. I дійсно так виглядало, і з точки зору наявності 52-мільйонного населення, республіки $з$ другим, після Росії, за величиною потенціалом розвинутої індустрії, і $з$ точки зору потужного наукового і кадрового потенціалу суспільства, його рівня освіченості, та й з багатьох інших параметрів прогнозного оцінювання. Проте, цей чималий потенціал значною мірою виявився змарнованим ${ }^{8}$. Якщо об'єктивно оцінювати сучасний стан України і порівнювати $з$ ймовірними, але не досягнутими результатами, то, звичайно, дуже

1 T. Kuzio, Independent Ukraine: Nation-State Building and Post-communist Transition, Routlege, New York 2015.

2 A. Åslund, How Ukraine Became a Market Economy and Democracy, Columbia Universuty Press, New York 2009.

3 B. Harasimiv, Post-communist Ukraine, Canadian Institute of Ukrainian Studies Press, 2002.

4 O. Fisun, Rethinking Post-Soviet Politics from a Neopatrimonial Perspective, Democratizatsiya, „The Journal of Post-Soviet Democratization” 2012, Vol. 20, No. 2, p. 87-96.

5 N. Rotar, Politična učast' gromadân Ukraïni u sistemnih transformaciâh perehidnogo periodu, Ruta 2007.

6 Û. Maciêvs'kij, U pastcì gibridnostì: zmìni transformaciï političnogo režimu v Ukraïni (1991-2014), Černìvcì 2016.

7 T. Lâšenko, Doslidžennâ suspil'no-političnogo tranzitu Ukraïni vitčiznânimi včenimi, „Vìsnik Dnìpropetrovs'kogo unìversitetu, Seriâ: fillosofiâ, socìologiâ, polìtologiầ" 2016, Vipusk 3, c. 46-57.

8 V. Kobil'nik, Osoblivostì startovoï situacï demokratičnogo tranzitu v Ukrä̈nì ta Pol'sii, v: Zbìrnik statej „Polìtologičnì studiī” 2010, Vipusk 1, c. 72-82. 
шкода за втраченими і нереалізованими можливостями, які пострадянська Україна мала на початку свого шляху дорогою незалежності.

Відзначу, що економічні зміни відбувались в Україні дуже суперечливо, тому що за понад семидесятирічне існування радянської влади на більшості території України українці значною мірою втратили почуття та навички господарів. Та вони, власне, і не могли їх зберегти в тих умовах комуністичної системи управління суспільством, економікою та державою, яка панувала у СРСР. Адже примусова колективізація, жахи голодомору, масові репресії нанесли відчутні травми українському народу, підірвали його не лише демографічний, але й інтелектуальний та морально-психологічний потенціал. Додам досить важливе зауваження, що ідеологічний та політичний пресинг радянської влади на периферії Союзу був більш суворим, аніж в його центрі. I це відчувалось за багатьма показниками в Радянській Україні. Всі ці чинники не могли не вплинути на пострадянські економічні та соціальні зміни в Україні. Хоча в країні побудовано певну модель ринкової економіки, але значною мірою вона залишається криміналізованою, недостатньо контрольованою державою, а тим більше - через державу безпосередньо суспільством. За різними оцінками «в тіні» перебуває від 40\% до 50\% валового національного продукту 9 . Ясна річ, що такий стан не може викликати оптимізму і захоплення, навпаки, він становить значні виклики для розвитку держави, адже слугує джерелом системної корупції, призводить до ухилення від податків, зменшення бюджетних надходжень, отже, в цілому обмежує можливості держави розвивати економічну і соціальну сфери суспільства.

Водночас, економічні результати поступу України навіть у роки відносної стабілізації або позитивної динаміки економічного і промислового розвитку переважно перерозподілялися на користь дуже обмеженої групи еліти. Власне кажучи, мова може йти про кількасот сімей, які мали безпосередній контроль над основними економічними активами України, і ще кілька десятків тисяч тих, кого варто розглядати як їх клієнтелу. Таким чином, звертаючись до доробку своїх колег, які досліджують сучасні політичні процеси з точки зору теорії неопатримоніалізму ${ }^{10}$, насамперед харківського науковця О. Фісуна,

9 V. Vasenko, Tìn'ova ekonomika kraïni ta šlâhi ï detìnizaciï, „Vìsnik Čerkas'kogo unìversitetu" 2016, № 1, c. 15-23.

10 O. Fìsun, Političnij režim Ukraïni u porìvnâl'nij perspektivi, „Strategičnì prìoriteti” 2008, № 1, c. 5-12. 
можна стверджувати, що в Україні економічна і соціальна модель базується на принципах патрон-клієнтських взаємин. Відтак засадничі принципи неопатримоніалізму досі залишаються актуальними для характеристики чинного стану соціально-економічного розвитку України $^{11}$, на що не змогли вплинути навіть результати Революції гідності.

Соціальні зміни в Україні характеризуються неоднозначними процесами. Інтегральним і переконливим показником розвитку певної держави, в тому числі показником успішності або неуспішності їі соціально-економічних і політичних трансформацій, є зміст і динаміка демографічних процесів. Конкретизуючи цей постулат щодо України, необхідно визнати, що за роки незалежності демографічні процеси в Україні характеризуються від’ємними показниками. Насамперед, населення країни зменшилось, за приблизними оцінками, з 52 до 42 мільйонів ${ }^{12}$, що є дуже вражаючим і тривожним показником. Далі, за показником співвідношення смертності та народжуваності - це співвідношення було, переважно, два до одного. I цей показник нині недалеко відхилився в кращу сторону. Відбувається також, але це типово для всієї Свропи, старіння населення, що також має далекосяжні негативні наслідки. Такі процеси призводять до значної депопуляції, ускладненої масштабною еміграцією українців і триваючою трудовою міграцією. Остання позначена перспективою переростання у безповоротну еміграцію з України. Це знаходить вияв у втраті Україною значної частини свого демографічного, кадрового й інтелектуального потенціалу. Необхідно підкреслити, що цю втрату стимулює також доволі виразна неповага як із боку політичної еліти, так i, на жаль, значної частини суспільства до того інтелектуального й кадрового потенціалу, який все ще зберігається в нашій державі. I вже лише в силу наведених аргументів соціальні зміни характеризуються складністю, суперечливістю i, нерідко, інтегральною негативною динамікою ${ }^{13}$. Наведу ще один фактор саме такого характеру цих змін. Справедливо вважається, що опорою ліберальної демократії є потужний середній клас. Всі спроби побудувати в Україні такий середній клас у найкращі роки

11 A. Ganža, Neopatrimonial'nij političnij režim v Ukraïnì 2010-2015: analìz funkcìnuvannâ političnoï sistemi, „Vìsnik Harkìvs'kogo nacìonal'nogo unìversitetu ìmenì V.N. Karazìna”, serìâ: „Polìtologiâ” 2016, Vipusk 28, c. 56-62.

12 O. Paliênko, Demografična kriza v Ukraïni: šlâhi ï̈ podolannâ, „Mologij včenij” 2017, № 9.1 (49.1), c. 134.

13 V. Čaban, Riven' žittâ naselennâ âk pokaznik stanu ekonomiki kraïni, „Ekonomìnnij vìsnik unìversitetu" 2016, № 31 (1), c. 185-186. 
iï незалежного існування, за відсутності зовнішньої агресії і масштабних внутрішніх потрясінь, виводили нас на експертні показники максимально близько 12-14\% представників такого класу в соціальній структурі суспільства. Щоправда, самі себе з середнім класом ототожнювали в окремі роки значно більше українців - до $40 \%$, а інколи й більше. Але така самоідентифікація нерідко не витримувала перевірки на відповідність базовим критеріям належності до середнього класу. Адже за іншими даними, рівень бідного населення в останні роки сягав $70-72 \%{ }^{14}$. Не дивно, що існуюча соціальна опора демократичним змінам в Україні $\epsilon$ доволі хиткою, а авторитарні рецидиви набувають хронічних проявів.

На загал, соціальна структура українського суспільства характеризується безповоротним зламом радянської, доволі міфологізованої трьохскладової моделі: робітничий клас, трудове (колгоспне, переважно, і радгоспне) селянство, а поміж ними - прошарок у вигляді трудової інтелігенції. Нова соціальна структура України стала більш строкатою, динамічною, фрагментованою. Але водночас вона ще далеко не відповідає соціальним структурам і показникам розвитку сучасних соціальних страт і прошарків у країнах СС, які забезпечували б Україні соціальну стабільність, економічний розвиток і надійну політичну перспективу побудови ефективної ліберальної демократії. Насамперед, йдеться про різку і таку, що триває далі поляризацію між незначним прошарком дуже багатих і більшістю бідних, при незначній питомій вазі середнього класу в Україні. В таких умовах залишається також відкритим для дискусій питанням і формування нової політичної нації в Україні. Хоча з оптимізмом відзначу, що події 2013-2014 pp. і триваючого досі конфлікту з Росією на території України призвели до значного зростання рівня консолідованості української нації і сприяли пришвидшенню формування новітньої політичної ідентичності українців. Останні експертні опитування (на жаль, в Україні з 2001 р. не проводився перепис населення) й інші соціологічні дані показують, що все ж таки ці катаклізми 2013 і наступних років виступили каталізатором процесів формування новітньої української політичної нації. Втім, вони $\epsilon$ неоднозначними й суперечливими ${ }^{15}$. Консолідуючий компонент зрілої громадянської самосвідомості і відповідальної поведінки, 3 одного боку, а також елементи етнонаціональних виявів, у тому числі

14 V. Skvorec', Formuvannâ lìnì rozlomu v ukraïns'komu suspil'stvì, „Gumanitarnij vìsnik ZDİA" 2017, Vipusk 70, c. 96-97.

15 V. Vasûtins'kij, Pozicï meškancìv shodu ì zahodu Ukrä̈ni âk osnova majbutn'ogo cìnnisnogo porozumìnnâ, „Ukraïns'kij psihologičnij žurnal” 2017, № 1 (8), c. 8-15. 
в їх радикальних і шовіністичних формах, з іншого, перебувають у складному співвідношенні, виглядають незбалансованими ${ }^{16}$.

Найважливіше, на чому варто акцентувати увагу, це те, що українська держава як до подій 2013-2014 рр., так і після цих трагічних зламів все ще не спромоглася виробити ефективну, продуману, систематизовану етнополітику як на загальнонаціональному, так і на регіональних рівнях. На превеликий жаль, це залишається вимогою невеликого кола експертів, незначного кола вітчизняних публічних інтелектуалів і громадських активістів, але не пріоритетною турботою державницької частини політичної еліти, політичного класу i, на жаль, значної частини українського суспільства в цілому. I небезпека настання вибухових наслідків від такого послідовного і триваючого досі зневажливого підходу наростає.

\section{Досвід політичних трансформацій: рух «зачарованим» колом}

Переходячи до викладу у другій частини статті, до певних узагальнень щодо тенденцій та спрямованості політичних трансформацій в Україні, зазначу, що український шлях розвитку часом виглядає як блукання зачарованим, замкненим колом. Спробую розкрити цю тезу в ряді положень. Характеризуючи основні тенденції розвитку політичної системи України, треба зазначити, що при тому загальному спрямуванні їі еволюції на демократизацію, а саме побудову ліберальної демократії, країна опинилася в специфічній ситуації ${ }^{17}$. А саме в тій, коли проголошена деюре і закріплена Конституцією України, законами, іншими нормативноправовими актами ліберально-демократична модель політичної системи України та їі режиму як ядра цієї політичної системи водночас перебуває в дисонансі з відновлюваними, повторюваними, а часом відверто домінуючими авторитарними тенденціями ${ }^{18}$. Ця вагома складова динаміки й драматизму розвитку української політичної системи, яку ми розглядали зокрема у спільній науковій статті з професор Н. Ротар ${ }^{19}$, потребує

16 S. Pirožkov, N. Hamìtov, Ukraïns'ke suspil'stvo na šlâhu konsolidacï, „Vìsnik Nacìonal'noï Akademiï Ukraïni” 2017, c. 43-52.

17 O. Kotukov, Trudnoŝì demokratičnogo tranzitu v Ukraïnì, „Teoriâ ta praktika deržavnogo upravlìnnâ" 2009, № 3, c. 77-85.

18 V. Tomahìv, Transformaciâ političnogo režimu v nezaležnì Ukraïnì: zagal'nì tendenciï, osoblivostì definicij, ,Ukraïns'ka nauka: minule, sučasne, majbutnê” 2014, № 19 (1), c. 336-342.

19 A. Kruglašov, N. Rotar, Avtoritarni deviaciï političnogo režimu v Ukraïnì, v: Sučasna ukrä̈ns'ka politika, Kiïv 2011, c. 162-176. 
подальшого уважного вивчення, як їі внутрішніх ресурсів і чинників, так і зовнішніх підтримуючих впливів. Авторитарні тренди, як добре відомо з багатого емпіричного матеріалу, переважають на пострадянському просторі. Адже тут, за винятком балтійських держав, які з 2004 р. стали повноцінними членами СС і НАТО, за той самий час інші держави або перетворились у консолідовані авторитарні режими (РБ, РФ та деякі інші), або перебувають в складному становищі коливань поміж гібридною чи то фасадною демократією, і спробами побудувати той чи інший варіант авторитаризму (Молдова та Грузія, наприклад).

Для розуміння природи протистояння між прихильниками різноспрямованих векторів розвитку української політичної системи особливе значення має аналіз такої ії складової як партійна система. Адже надії, які були пов'язані з розбудовою сучасної партійної системи в Україні, покладались на те, що партії стануть важливим засобом демократизації суспільства. Від них очікувалось, що вони, по-перше, будуть джерелом, механізмом, інструментарієм створення в Україні ідеологічного і політичного плюралізму. По-друге, зможуть найбільш ефективно доносити запити, інтереси та вимоги громадян до державних інституцій, до «входу» у вітчизняну політичну систему. По-третє, ïx змагання породжуватимуть конкурентне середовище в партійній і політичній еліті України і, відтак, дозволятимуть громадянам робити вибір серед кращих, серед тих, хто претендує на отримання влади в країні в цілому і в їі окремих регіонах.

На жаль, партійна система в Україні, з одного боку, здебільшого тяжіла до формальної атомізованості і еклектичної строкатості, якщо брати до уваги лише кількісні їі виміри і параметри розвитку. А з іншого боку, якщо розглядати її змістовні характеристики, то в Україні майже немає впливових ідеологічних партій, хоча, в принципі, цей тренд є загальносвітовим і європейським. Важливіше інше - у нас немає таких політичних партій, які б розбудовувалися за ініціативи «знизу», або хоча б спиралися на реальну підтримку громадян поза межами виборчого процесу. Переважно це партії, які побудовані за принципом «саtch it all», або «хапай все, що зможеш», і йдеться не лише про голоси виборців, а насамперед про доступ до ресурсів держави і намагання максималізувати вигоди від їх експлуатації. Також це партії, які $є$ символічним, брендовим оформленням претензій або реального впливу на владу з боку фінансово-промислових груп, або, точніше, провідних олігархічних кланів. 
Звідси назвати розбудову партійної системи в Україні цілком чи навіть переважно успішною, визначати іï як позитивний фактор процесів демократизації вітчизняної політичної системи передчасно. Це твердження може підтримати аналіз такого показника демократичного розвитку України як еволюція ії виборчої системи ${ }^{20}$. Попри те, що Україна перепробувала різні варіанти системи виборів до Верховної Ради, до місцевих рад і представницьких органів влади (мажоритарна, пропорційна, ті чи інші формати змішаної системи) ${ }^{21}$, наша держава досі не спромоглася створити стабільну виборчу систему і забезпечити якісне функціонування виборчого процесу, який би в повній мірі відповідав загальновизнаним демократичним стандартам (наприклад, Ради Європи, ЄС, до якого ми прагнемо), а найголовніше, який би адекватно відбивав інтереси виборців ${ }^{22}$. Йдеться і про те, що виборчі закони України часом зазнають радикальних змін напередодні нових виборів на догоду нестійкому компромісу правлячих елітних угруповань щодо правил електоральної гри. Що характерно, цей компроміс зазвичай швидко руйнується після завершення виборів. Особливо недоліки кланово-олігархічного підходу до створення електоральних правил виявляються у виборах на місцях, які за виборчою системою 2015 р. нерідко призводять до того, що депутати місцевих рад $\epsilon$ дуже далекими від інтересів своїх виборців і фактично непідконтрольні їм. В кращому випадку, вони озвучують і забезпечують трансляцію інтересів своєї партійної верхівки, а в гіршому, цинічно використовують ці партійні бренди, насправді відстоюючи апетити місцевих груп інтересів, насамперед, бізнес-акторів локального та регіонального рівня. До того ж, нерідко ці місцеві бізнес-інтереси $є$ за своєю природою переважно тіньовими, або, що ще гірше, належать до «чорного сектору» української економіки та політики. Ось тому виборча система в Україні $\epsilon$ не тільки не оптимальною, але й за багатьма своїми показниками дисфункціональною. Сумарно вона (ре)продукує той результат, який раніше чи пізніше призводить до відкритого конфлікту між, з одного боку,

20 L. Kostec'ka, Problemi regulûvannâ viborčogo procesu v Ukraïnì, „Naukovì zapiski Ìnstitutu zakonodavstva Verhovnoï Radi Ukraïni” 2017, № 1, c. 154-156.

21 Û. Ostapec', Elektoral'ni procesi na Zakarpattì u kontekstah zagal'nonacional'nih viborì, Užgorod 2016, c. 10-19.

22 T. Zavorotčenko, Problemi zahistu viborčih prav gromadân u kontekstì pobudovi gromadâns 'kogo suspil'stva, „Naukovij vìsnik Užgorods'kogo nacìnal'nogo unìversitetu”, seriâ: „Pravo” 2016, Vipusk 36 (1), c. 55-58. 
інститутами влади в центрі та в регіонах і, відповідно, з іншого, зі значною частиною громадянського суспільства.

Подібні суперечності можна побачити й у сфері відносин між політичною елітою і так званими пересічними громадянами. За роки соціально-політичних трансформацій і становлення української держави політична еліта в цілому, а управлінська еліта в Україні зокрема ${ }^{23}$, особливо iï верхівка, значною мірою відірвалися від запитів та інтересів, а тим більше від стандартів життя своїх співгромадян. Більш того, такий розрив вони почали сприймати як об'єктивну даність, як шанс дарований саме їм, а також їхнім нащадкам, i, виходячи з цього, почали вибудовувати свою стратегію політичної поведінки і тактику дій в просторі ситуативної політики. Звідси між політичною елітою і громадянами існує величезне напруження, конфлікти і розрив інтересів. I цей конфлікт інтересів та моделей поведінки не подоланий донині навіть унаслідок тих революційних зрушень і процесів, які мали місце за доволі коротку новітню історію України ${ }^{24}$. Маю на увазі революційні імпульси, задані, зокрема, Помаранчевою революцією, яка блокувала прихід Віктора Януковича і його Партії Регіонів до влади в 2004-2005 pp., та події 2013-2014 pp., які отримали дуже високу, зобов'язуючу, але не завжди виправдану за результатами, назву «Революція гідності». Хоча сам імпульс до цих подій відповідає цій назві, і я вважаю, що в цьому плані ця метафора заслуговує на використання, в тому числі в науковій літературі.

Отже, революційні імпульси, які виникали в Україні, нерідко виявлялися скерованими і відповідно «прагматично утилізованими» альтернативними фракціями в середовищі існуючої політичної еліти. Саме тому вони не призводили ані до радикальних змін у самому іiі середовищі, ані, як наслідок цього, до відповідних змін політичного режиму та політичної системи України ${ }^{25}$. Певні і значно більші, ніж раніше надії покладалися на процеси, пов'язані зі змінами після 2013-2014 pp. Зміни відбуваються - заперечувати їх значення неможливо. Але саме тут, серед іншого, спрацьовують ті рефлекси соціальної та політичної мімікрії, які винесені у назву статті. Можна стверджувати, що ці необхідні зміни для успі-

23 T. Tomaševs'ka, Prioritetni funkciï politiko-upravlìns'koï eliti na sučasnomu etapì deržavotvorennâ, ,Aspekti publičnogo upravlìnnâ” 2016, № 1-2, c. 56.

24 G. Kuc, Peripetï formuvannâ političnogo režimu v postradâns'kij Ukraïnì: dosvìd majdaniv, „Sučasne suspìl’stvo” 2014, № 1, c. 82-94.

25 M. Stepiko, Pro ukraïns'kij šlâh do demokratï̈, „Strategìcnì prìoriteti” 2016, № 3, c. $270-272$. 
ху державності та демократії в Україні відбуваються тільки тоді, коли їх уже неможливо не проводити. Тобто, коли буде сформована більш-менш консолідована та вимоглива позиція громадянського суспільства, здійснюватиметься відчутний та цілеспрямований зовнішній тиск на українську політичну й управлінську еліту і вона, у свою чергу, не матиме ресурсів для подальшого зволікання з реформами, зокрема, шляхом їх бурхливої імітації. В іншому випадку - реформи здійснюються зі значними зволіканнями, або їх зміст вихолощується. I ці обставини також треба визнати як фактор, який дестабілізує пост-революційний розвиток України.

Обравши, нарешті, європейський вектор розвитку України, зокрема підписавши Асоціацію з Свропейським Союзом, створюючи з ним Зону вільної торгівлі, нехай і асиметричну, але всеохоплюючу, отримавши, завдяки нашим європейським партнерам, а також завдяки позиції українського громадянського суспільства і європейської частини ії еліти, безвізовий режим, ми можемо вести мову про те, що Україна все ж таки поступово переходить на якісно новий рівень розвитку. В тому числі і у взаєминах з її стратегічними партнерами, серед яких важливе місце займала і повинна посідати надалі Польща.

Але разом із цим, хочу наголосити на наступному. Займаючись вивченням процесів європейської інтеграції загалом і європейської інтеграції України зокрема чимало років (власне з 1993 р.), вважаю, що здобутки на цьому шляху в Україні і ті проблеми, які залишаються невирішеними, перебувають між собою у складному балансі. На мій особистий погляд, проблемні питання, що потребують вирішення, переважають поки що над нашими здобутками. Візьмемо до порівняння той шлях, який пройшла Польща й інші посткомуністичні держави Центральної і Східної Європи до ЄС і НАТО. Вони пройшли його за період, беручи максимальні показники, з 1989 до 2007 pр. Україна торує його вже 26-й рік, а якщо взяти з офіційного чіткого проголошення європейського вектору Указами Президента України з 1997-1998 pp., то 20 років. І те, що здобули ці держави, і що здобуває Україна - це на разі різнорівневі явища, в тому числі, за сутнісними, якісними параметрами ${ }^{26}$. Таким чином, довгий час європейський вектор розвитку офіційним Києвом радше декларувався і нерідко слугував знаряддям політичної пропаганди й електоральних ма-

26 I.M. Koval', O.Ì. Brusilovs'ka (red.), Mižnarodnì vidnosini ta politika deržav v umovah global'nih transformacìj: analiz sučasnoï političnoï dumki, Odesa 2016, c. 127-153. 
ніпуляцій, засобом зовнішньої і внутрішньої легітимізації політичного курсу правлячої еліти, а не був детермінантою та імперативом як політичної поведінки, так і етичних настанов еліти й суспільства. 3 чого час зробити чимало конкретних висновків.

\section{Висновки}

Переходячи до підсумкових висновків, я запропоную певні попередні узагальнення. Насамперед, значним позитивом пострадянського періоду розвитку України $\epsilon$ те, що українська держава довела свою спроможність вистояти під шаленим тиском і в дуже несприятливих внутрішніх та зовнішніх умовах, починаючи з 2013 р. По-друге, важливим надбанням $€$ те, що українське суспільство й еліта, в чому вони виглядають більш консолідованими, визначилися зі стратегічними напрямками свого розвитку - це європейський вектор, європейська інтеграція, демократичні процеси і демократизація, а також євроатлантична інтеграція. Але навіть закріплена в нових законах України визначеність цього вектора розвитку ускладнюється в його практичній реалізації тим, що залишаються невизначеними правила гри, причому як для еліти, так і для суспільства в цілому. Залишається відкритим надзвичайно широкий простір для маніпуляцій, для суб'єктивізму і показного популізму, який також притаманний сучасній Україні, але за браком часу ці питання залишились осторонь розгляду в цій статті.

Важливим і неоднозначним за своєю впливовістю чинником розвитку української державності і трансформаційних процесів у ній $є$ фактор зовнішньої загрози, насамперед, з боку Російської Федерації ${ }^{27}$. Варто згадати знамениті слова Володимира Путіна, так би мовити, національного лідера Росії, звернені до Джорджа Буша-молодшого: «Джордж, Україна це взагалі не держава». I його, теж дуже зловісні для України, публічні просторікування про те, що український і російський народ - це навіть не братні народи, а єдиний народ. 3 історичного досвіду доволі добре відома сфера застосування концепції «єдиного народу», яка призвела до аншлюсу Австрії нацистською Німеччиною і до наступних агресивних дій, що завершилися розв'язанням Другої світової війни. Тому все це далеко не безневинні заяви аматорського гравця в етнологію. Ось тому

27 T. Kuzio, Ukraine Between a Constrained EU and Assertive Russia, „JCMS: Journal of Common Market Studies” 2017, Vol. 55, No. 1, p. 103-120. 
також зовнішня загроза національній безпеці для України стає тим визначальним викликом, який впливає на іï розвиток і процеси трансформації на прийдешні роки.

Нарешті, якщо розглядати певні характеристики самого українського суспільства, його не тільки управлінсько-політичної, але й інтелектуальної еліти, то умовно можна визначити три важливі групи, які визначають перебіг розвитку України. По-перше, реформатори як активна меншість, яка справді намагається змінити Україну на краще, відповідно до європейських стандартів і норм західної цивілізації. По-друге, $\epsilon$ більш численні й часом не менш завзяті імітатори, які вдаються, здебільшого вимушено (тому що це забезпечує їм доступ до ресурсів, збереження свого статусу і впливів), до кон'юнктурно зумовленої мімікрії і імітації під реформаторів. По-третє, $\epsilon$, нарешті, чимала група консерваторів, які не заперечують необхідності реформ, але прагнуть всіма засобами мінімізувати як зміст їх порядку денного, так і вплив реформаційних сил на політичну систему та її складові елементи, на інституційний дизайн української держави, українське суспільство, економіку в цілому. Насамкінець, є група людей, яких можна умовно назвати реставраторами. Як прорадянського штибу, взірцем якого можна вважати, наприклад, Петра Симоненка - протягом тривалого часу лідера комуністів, реставраторів проросійського, імперського кшталту, наприклад, в особі Ігоря Гіркина - «героя» фейкової «Новоросії», частково деяких наших крайніх правих, які намагаються збудувати Україну з тих позицій, які реанімують героїчний пафос і категорії мислення підпілля та руху опору 1930-1940-х рр. Останні нерідко виступають за таку Україну, яка не бере участі ані в європейських, ані в євразійських процесах інтеграції, а тому всі ці «реставраційні зусилля» також вимагають глибшого наукового аналізу як з боку політологів, культурологів, соціологів, так і з боку істориків.

Проте, завершуючи цей текст, хочу висловити важливу, як на мене, думку. Необхідно відзначити, що всі ці труднощі - величезна й справді трагічна ціна, яку Україна сплачує і за своє проблематичне геополітичне становище, і за помилки власної політичної еліти, і за наївність, довірливість, а часом майже невиліковну інфантильність і соціальну безвідповідальність частини суспільства. Разом із цим, не варто замовчувати незацікавленість частини наших західних і світових друзів інвестуванням у свою власну безпеку і перспективи розвитку шляхом підтримки демократичного та європейського вектору розвитку України. Але всупереч 
цьому, всупереч співіснуванню з державою, яка, як виглядає нині, цілком серйозно поставила собі за мету втілення в життя ретроімперських амбіцій та концепцій, Україна відбувається. I відбувається вона як країна, як суспільство і як державність. Тому спільними зусиллями українських громадян, європейської частини вітчизняної еліти, яка сповідує й реалізує, а не імітує відданість європейським цінностям, а також за дружньою та вимогливою допомогою наших європейських і світових друзів, Україна відбудеться як повноцінна демократична і європейська держава.

\section{Bìblìografîâ}

Åslund A., How Ukraine Became a Market Economy and Democracy, Columbia Universuty Press, New York 2009.

Čaban V., Riven’ žittâ naselennâ âk pokaznik stanu ekonomiki krä̈ni, „Ekonomičnij vìsnik unìversitetu" 2016, № 31 (1).

Fìsun O., Političnij režim Ukraïni u porivnâl'nìj perspektivì, „Strategì̌nì prìoriteti” 2008, № 1 .

Fisun O., Rethinking Post-Soviet Politics from a Neopatrimonial Perspective, Democratizatsiya. „The Journal of Post-Soviet Democratization” 2012, Vol. 20, No. 2.

Ganža A., Neopatrimonial'nij političnij režim v Ukraïnì 2010-2015: analiz funkcìnuvannâ političnö̈ sistemi, „Vìsnik Harkìvs'kogo nacìonal'nogo unìversitetu ìmenì V.N. Karazìna”, seriâ: „Polìtologiâ” 2016, Vipusk 28.

Harasimiv B., Post-communist Ukraine, Canadian Institute of Ukrainian Studies Press, Edmonton 2002.

Kobil'nik V., Osoblivostì startovoï situacï̈ demokratičnogo tranzitu v Ukraïnì ta Pol'si, v: Zbìrnik statej „Polìtologičnì studiï” 2010, Vipusk 1.

Kostec'ka L., Problemi regulûvannâ viborčogo procesu v Ukraïnì, „Naukovì zapiski Ìnstitutu zakonodavstva Verhovnoï Radi Ukraïni” 2017, № 1.

Kotukov O., Trudnoŝi demokratičnogo tranzitu v Ukraïnì, „Teoriâ ta praktika deržavnogo upravlìnnâ” 2009, № 3 .

Koval' I.M., Brusilovs'ka O.Ì. (red.), Mižnarodnì vidnosini ta politika deržav v umovah global'nih transformacìj: analiz sučasnoï političnoï dumki, Odesa 2016.

Kruglašov A., Rotar N., Avtoritarni deviaciï političnogo režimu v Ukraïnì, v: Sučasna ukraïns 'ka politika, Kiïv 2011.

Kuc G., Peripetï formuvannâ političnogo režimu v postradâns 'kìj Ukraïnì: dosvìd majdanìv, „Sučasne suspill'stvo” 2014, № 1.

Kuzio T., Independent Ukraine: Nation-State Building and Post-communist Transition, Routledge, New York 2015.

Kuzio T., Ukraine Between a Constrained EU and Assertive Russia, „Journal of Common Market Studies" 2017, Vol. 55, No. 1.

Lâšenko T., Doslidžennâ suspil'no-političnogo tranzitu Ukrä̈ni vitčiznânimi včenimi, Vìsnik Dnìpropetrovs'kogo unìversitetu, seriâ: „Fìlosofiâ, socìologîa, polìtologiâ” 2016, Vipusk 3.

Maciêvs'kij Û., U pastcì gibridnostì: zmìni transformacï̈ političnogo režimu v Ukraïnì (19912014), Černìvcì 2016. 
Досвід політичних трансформацій в Україні: від рефлексів мімікрії до імперативу...

Ostapec' Û., Elektoral'nì procesi na Zakarpattì u kontekstah zagal'nonacional'nih viborìv, Užgorod 2016.

Paliênko O., Demografična kriza v Ukraïni: šlâhi iï podolannâ, „Mologij včenij” 2017, № 9.1 (49.1).

Pirožkov S., Hamìtov N., Ukraïns 'ke suspil'stvo na šlâhu konsolidaciï, „Vìsnik Nacìonal'noï Akademiï Ukraïni” 2017.

Rotar N., Polìtična učast'gromadân Ukraïni u sistemnih transformaciâh perehìdnogo perìodu, Ruta 2007.

Skvorec' V., Formuvannâ lìnij rozlomu v ukraïns 'komu suspil'stvì, „Gumanìtarnij vìsnik ZDİA” 2017, Vipusk 70.

Stepiko M., Pro ukraïns 'kij šlâh do demokratï̈, „Strategì̌nì prìoriteti” 2016, № 3.

Vasenko V., Tìn'ova ekonomika kraïni ta šlâhi ïi detìnizacï̈, „Vìsnik Čerkas'kogo unìversitetu” 2016, № 1.

Vasûtins'kij V., Poziciï meškanciv shodu ì zahodu Ukraïni âk osnova majbutn'ogo cìnnisnogo porozuminnâ, „Ukraïns'kij psihologičnij žurnal” 2017, № 1 (8).

Zavorotčenko T., Problemi zahistu viborčih prav gromadân u kontekstì pobudovi gromadâns'kogo suspil'stva, „Naukovij vìsnik Užgorods'kogo nacìonal'nogo unìversitetu”, serìa: „Pravo" 2016, Vipusk 36 (1).

Tomahìv V., Transformaciâ političnogo režimu v nezaležnìj Ukraïnì: zagal'nì tendencï̈, osoblivosti definicìj, „Ukraïns'ka nauka: minule, sučasne, majbutnê” 2014, № 19 (1).

Tomaševs'ka T., Prìoritetnì funkciï politiko-upravlìns 'koï elìti na sučasnomu etapì deržavotvorennâ, „Aspekti publì̌nogo upravlìnnâ” 2016, № 1-2. 